\title{
Results of Meteorological Observations taken at Jerusalem in the Year 1892
}

\section{James Glaisher}

To cite this article: James Glaisher (1896) Results of Meteorological Observations taken at Jerusalem in the Year 1892, Palestine Exploration Quarterly, 28:3, 264-271, DOI: 10.1179/ peq.1896.28.3.264

To link to this article: http://dx.doi.org/10.1179/peq.1896.28.3.264

Published online: 20 Nov 2013.

Submit your article to this journal $₫$

Џ Article views: 4

Q View related articles $\square$ 


\title{
RESULTS OF METEOROLOGICAL OBSERVATIONS TAKEN AT JERUSALEM IN THE YEAR 1892.
}

\author{
By James Glaisher, F.R.S.
}

THe numbers in column 1 of this table show the highest reading of the barometer in each month; of these the highest, as usual, are in the winter, and the lowest in the summer months; the maximum for the year was 27.617 inches, in December, and the next in order, 27.604 inches, in January. The highest reading in the preceding 31 years, viz., 1861 to 1891 inclusive, was $27 \cdot 816$ inches, in December, 1879.

In column 2 the lowest reading in each month is shown; the minimum for the year was 27.100 inches, in February, and the next in order, $27 \cdot 125$ inches, in July. The lowest reading in the preceding 31 years was 26.972 inches, in April, 1863, and February, 1865.

The range of readings in the year was 0.517 inch. The largest range in the preceding 31 years was 0.742 inch, in 1876; and the smallest, 0.491 inch, in 1883.

The numbers in the 3rd column show the extreme range of readings in each month; the smallest, 0.131 inch, was in August, the next in order, 0.192 inch, in July; and the largest, 0.491 inch, in December; and the next in order, $0.472 \mathrm{inch}$, in January. The mean monthly range for the year was 0.303 inch. The mean for the preceding 31 years was 0.309 inch.

The numbers in the 4 th column show the mean monthly pressure of the atmosphere; the highest was 27.463 inches, in December, and the next in order, 27.432 inches, in January ; the lowest was 27.250 inches, in July, and the next in order, 27.280 inches, in August. The mean yearly pressure was $27 \cdot 358$ inches. The highest mean yearly pressure in the preceding 31 years was 27.443 inches, in 1861, and the lowest, $27 \cdot 359$ inches, in 1890. The mean for the 31 years was $27 \cdot 392$ inches.

The temperature of the air reached $90^{\circ}$ on May 14th, and was the only day in May of a temperature so high as $90^{\circ}$ (in the preceding 10 years, the earliest day in the year the temperature was $90^{\circ}$ was March 25 th in the year 1888); in June it reached or exceeded $90^{\circ}$ on 4 days; in July, 4 days; in August, 6 days; and in Sejtember, 8 days, the 24th being the last day in the year of a temperature as high as $90^{\circ}$. In the preceding 10 years the latest day in the year this temperature reached $90^{\circ}$ was October 23rd in 1887. The temperature reached or exceeded $90^{\circ}$ on 23 days during the year. In the years 1882 and 1891 the number of days of this high temperature was 28, and in 1887 was 73 ; the average of the 10 years was 43 . The highest temperature in the year was $101^{\circ}$ on September 17th. The highest in the preceding 10 years, 1882 to 1891 , was $106^{\circ}$, in July, 1888.

The temperature of the air was as low as $36^{\circ}$. on 3 nights, viz., January 26th, and December 19th and 20th. In'January it was as low or 


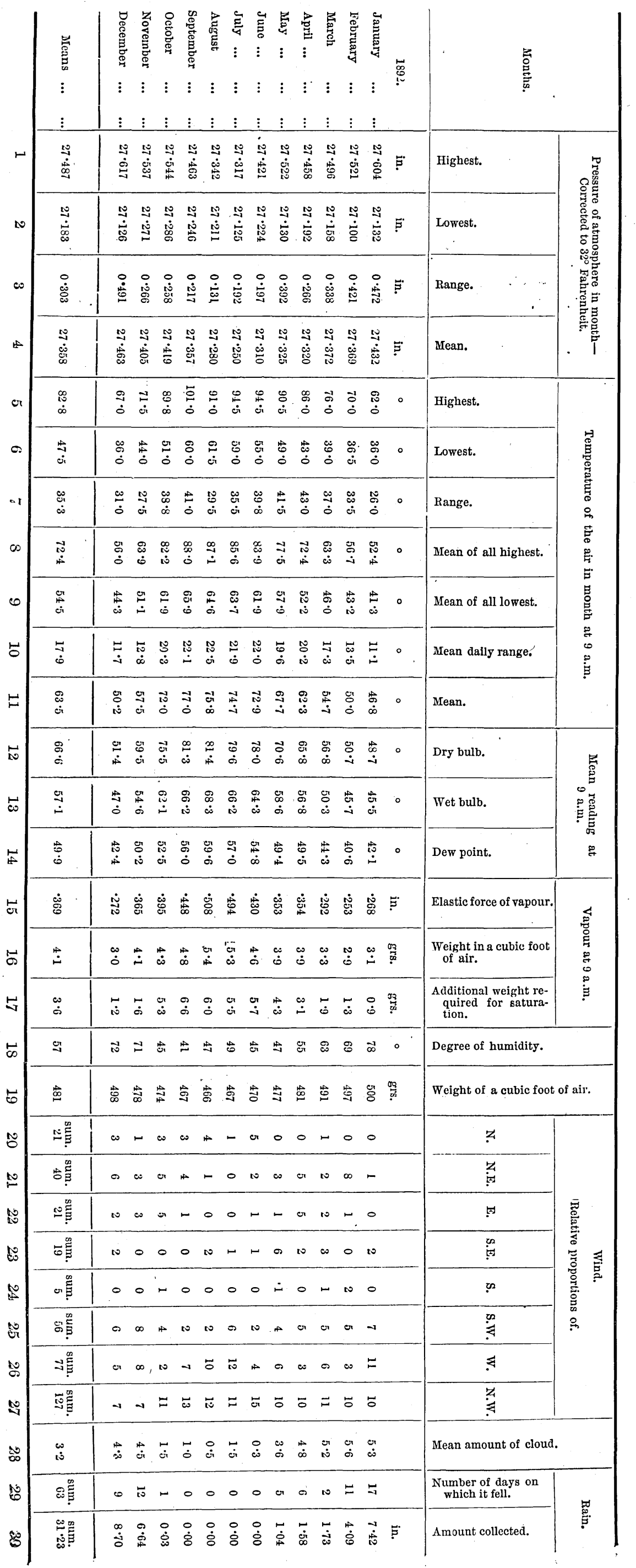


lower than $40^{\circ}$ on 9 uights ; in February on 4 nights ; in March on 1 night ; and in December on 5 nights. Thus the temperature was as low or lower than $40^{\circ}$ on 19 nights during the year. In the year 1885 the number of nights of this low temperature was 23 , and in 1886 was 97 ; the average for the 10 years was 52 . The lowest temperature in the preceding 10 years was $26^{\circ} \cdot 5$, in January, 1890.

The highest temperature of the air in each month is shown in column 5 . In January it was $62^{\circ}$, being $1^{\circ} \cdot 5$ above the mean of the ten high day temperatures in January. The high day temperature was above its average in Februar: April, Keptember, and December, and below in all other months. The mean for the year was $82^{\circ} \cdot 8$, being $1^{\circ} \cdot 3$ below the average of 10 years. The highest in the year was $101^{\circ}(0$, in September.

The lowest temperature of the air in each month is shown in column 6 . In both January and December it was $36^{\circ} \cdot 0$, being $4^{\circ} \cdot 2$ and $2^{\circ} \cdot 3$ respectively above their averages. The nights were warm throughout the year and abov: their av rages. The mean for the year was $47^{\circ} \cdot 5$, boing $3^{\circ} \cdot 0$ above th average of 10 years.

The range of temperature in each month is shown in column 7 ; the numbers vary from $26^{\circ} 0$ in Januar; to $43^{\circ}$ in May. In the months of March, August, and November the ral.ges were small, owing to the low high day and high night temperatures, leing $10^{\circ} \cdot 2,11^{\circ} \cdot 1$, and $8^{\circ} \cdot 4$ respectively less than their averages. The mean range for the year was $35^{\circ} 3$, being $4^{\circ} \cdot 2$ less than the average of 10 years.

The range of temperature in the year was $65^{\circ} 0$. The largest in the preceding 10 years was $76^{\circ} .5$, in each of the years 1884, 1886, and 1888, and the smallest, $63^{\circ} \cdot 5$, in the year 1885 .

The mean of all the high day temperatures in each month is shown in column 8. The lowest was $52^{\circ} \cdot 4$ in January, being $1^{\circ} \cdot 8$ higher than the average. The highest was $88^{\circ}$, in September, being $2^{\circ} .5$ above the average, and the next in order $87^{\circ} 1$, in August. The mean for the year was $72^{\circ} \cdot 4$, being $0^{\circ} \cdot 1$ above the average of 10 years.

The mean of all the low night temperatures is shown in column 9 . The lowest was $41^{\circ} \cdot 3$, in January, being $3^{\circ} \cdot 0$ higher than the average. The highest was $65^{\circ} \cdot 9$, in September, being $5^{\circ}$ higher than the average. The mean for the year was $54^{\circ} \cdot 5$, or $2^{\circ} \circ$ above the average of 10 years.

In column 10 the mean daily range of temperature in each month is shown; the smallest was $11^{\circ} \cdot 1$, in January, and the next in order, $11^{\circ} \cdot 7$, in December ; the greatest was $22^{\circ} \cdot 5$, in August, and the next in order $22^{\circ} \cdot 1$, in September. The mean for the year was $17^{\circ} \cdot 9$, being $1^{\circ} \cdot 9$ less than the average. The smallest ranges in the preceding 10 years were $9^{*} \cdot 3$, in January, 1883, and $9^{\circ} \cdot 7$, in December, 1890 ; the greatest were $33^{\circ} \cdot 8$, in August, 1886 , and $30^{\circ} \cdot 1$, in the same month of 1887 . The smallest mean for the year was $17^{\circ} \cdot 8$ in 1883 , and the greatest, $24^{\circ} \cdot 3$, in 1886 .

The mean temperature of the airr, as found from the maximum and minimum temperatures only, is shown in each month in column 11 ; the lowest was $46^{\circ} \cdot 8$, in $J$ anuary ; and the next in order $50^{\circ} 0$, in February ; the highest was $77^{\circ} 0$, in September, and the next in order $75^{\circ} .8$, in 
August. The mean for the year was $63^{\circ} .5$, exceeding the average of 10 years by $1^{\circ} \cdot 1$. The lowest mean temperatures in the preceding 10 years were $39^{\circ} .8$, in January, 1890 , and $42^{\circ} \cdot 0$, in December, 1886 ; the highest were $81^{\circ} \cdot 2$, in August, 1890 ; and $81^{\circ} \cdot 1$, in July, 1888. The highest mean for the year was $63^{\circ} \cdot 7$, in 1885 , and the lowest, $60^{\circ} \cdot 1$, in 1886.

January was the coldest month of the year, by reference to columns 5 and 6 it will be seen that, though the coldest month, it was above its average both by day and night; and the nights were warm and above their average throughout the year, particularly so in the months of January, March, and September.

The numbers in column 12 are the mean readings of a dry-bulb thermometer. If those in column 12 be compared with those in column 11, it will be seen that those in column 12 are a little higher in every month, the difference of the means for the year being $3^{\circ} \cdot 1$. The mean difference between the mean temperature of the air and that at 9 a.m. for the 10 years was $3^{\circ} \cdot 2$.

For a few days in the winter months the dry and wet-bulb thermometers read alike, or nearly so, but in the months from May to October the difference between the readings often exceeded $20^{\circ}$, and was as large as $31^{\circ} \cdot 6$ on September 16 th.

In column 13 the mean monthly readings of the wet-bulb are shown; the smallest differences between these and those of the dry-bulb were $3^{\circ} \cdot 2$, in January, and $4^{\circ} \cdot 4$, in December; the largest were $15^{\circ} \cdot 1$, in September, and $13^{\circ} \cdot 7$, in June. The mean for the year was $57^{\circ} \cdot 1$, and that of the dry was $66^{\circ} \cdot 6$; the mean difference was $9^{\circ} \cdot 5$.

The numbers in column 14 are the temperature of the dew-point, or that of the temperature at which the air would be saturated by the quantity of vapour mixed with it ; the smallest differences between these numbers and those in column 12 , were $6^{\circ} 6$, in January, and $9^{\circ} \cdot 0$ in December ; the largest were $25^{\circ} \cdot 3$, in September, and $23^{\circ} \cdot 2$ in June. The mean temperature of the dew-point for the year was $49^{\circ} .9$; the mean for the 10 years was $50^{\circ} \cdot 1$.

The numbers in column 15 show the elastic force of vapour, or the length of a column of mercury in inches corresponding to the pressure of vapour; the smallest was $0.253 \mathrm{inch}$, in February, and the largest, 0.508 inch, in August. The mean for the year was 0.369 inch; the average of 10 years was 0.375 inch.

In column 16 the weight in grains of the water in a cubic foot of air is shown; it was as small as $2 \cdot 9$ grains in February, and as large as 5.4 grains in August. The mean for the year was 4.1 grains; the average of 10 years was $4: 1$ grains.

In column 17 the additional quantity of water required to saturate a cubic foot of air is shown; it was less than one grain in January, and more than $6 \frac{1}{2}$ grains in September. The mean for the year was 3.6 grains ; the average of 10 years was $3: 4$ grains.

The numbers in column 18 show the degree of humidity of the air, 
saturation being represented by 100 ; the largest numbers appear in January, February, March, November, and December ; and the smallest from April to October; the smallest of all was 41 in September. The mean for the year was 57 ; that of the 10 years was 59 .

The numbers in column 19 show the weight in grains of a cubic foot of air, under its mean atmospheric pressure, temperature, and humidity. The largest number was in January, decreasing month by month to the smallest in August, and then increasing to December. The mean for the year was 481 grains; that of the 10 years was 482 grains.

The most prevalent winds in January were W. and N.W., and the least prevalent winds were N., E., and S. ; in February the most prevalent were N.W. and N.E., and the least were N. and S.E.; in both March and April the most prevalent was N.W., and the least were N. and S.; in May the most prevalent was N.W., and the least was N.; in June the most prevalent was N.W., and the least was S. ; in both July and August the most prevalent were W. and N.W., and the least were N.E., E., and S. ; in September the most prevalent was N.W., and the least were S.E. and S.; in October the most prevalent was N.W., and the least was S.E.; in November the most prevalent were S.W., W., and N.W., and the least were S.E. and S. ; and in December the most prevalent winds were N.W. and S.W., and the least prevalent wind was S. The most prevalent wind for the year was N.W.; which occurred on 127 times, of which 15 were in June, 13 in September, and 12 in August ; and the least prevalent wind was S., which occurred on only 5 times during the year.

The total number of times of each wind are shown in the last line of columns 20 to 27 ; those winds.less in number than the average of the preceding 10 years were-

$\begin{array}{rrr}\text { N. } & \text { by } & 10 \\ \text { E. } & \# & 11 \\ \text { S.E. } & \Rightarrow & 10 \\ \text { S. } & \Rightarrow & 6\end{array}$

and those winds greater in number than the average of 10 years were-

$$
\begin{array}{rrr}
\text { N.E. by } & 2 \\
\text { S.W. } & 5 \\
\text { W. } & \text { " } \\
\text { N.W. ", } & 21
\end{array}
$$

The numbers in column 28 show the mean amount of cloud in each month; the month with the smallest amount is June, and the largest, February. Of the cumulus or fine weather clond there were 5 instances; of the nimbus or rain cloud 28 instances, of which 7 were in February, and 6 in January, and only 4 instances from April to October; of the cirrus there were 10 instances; of the cirro cumulus 69 instances; of the cumulus stratus 61 instances; of the cirro stratus 16 instances; 
and 177 instances of cloudless skies, of which 27 were in June, and 23 in both July and August, and 6 only in both February and March.

The largest fall of rain for the month in the year was 8.70 inches in December, of which 4.70 inches fell on the 1st, and 2.18 inches on the 2nd. The next largest fall for the month was 7.42 inches, in January, of which 1.10 inch fell on both the 1st and 31st, 1.09 inch on the 23rd, and 1.03 inch on the 19th. No rain fell from May 19th till October 31st, making a period of 164 consecutive days without rain. The total fall of rain for the year was 31.23 inches, being 6.00 inches above the average for 32 years, viz., 1861 to 1892. The number of days on which rain fell was 63 , being 8 more than the average.

\section{RESULTS OF METEOROLOGICAL OBSERVATIONS TAKEN AT TIBERIAS IN THE YEAR 1892.}

\section{By James Glaisher, F.R.S.}

The numbers in column 1 of this table show the highest reading of the barometer in each month; the highest appear in the winter, and the lowest in the summer months; the maximum for the year was 31.118 inches, in January, and the next in order 31.070 inches, in February.

In column 2 the lowest reading in each month is shown; the minimum for the year was 30.318 inches, in May; and the next in order $30 \cdot 321$ inches, in July.

The range of readings in the year was $0.800 \mathrm{inch}$, being 0.283 inch greater than the range at Jerusalem.

The numbers in the 3rd column show the extreme range of readings in each month; the smallest was 0.189 inch, in August, and the next in. order 0.216 inch, in July. The largest was 0.687 inch, in January, and the next in order 0.645 inch, in February.

The numbers in columns 4 and 5 show the mean monthly reading of the barometer at 8 a.m. and 4 p.m.; and those in column 6 the lower reading at 4 p.m. than at 8 a.m. ; the smallesc difference between these two readings was 0.032 inch, in November, and the next in order 0.043 inch, in February ; the largest is $0.107 \mathrm{inch}$, in October, and the next in order 0.104 inch, in June. In England in January the readings at 8 a.m. and 4 p.m. are practically the same; in all other months the reading at 4 p.m. is lower than at $8 \mathrm{a.m}$. ; the greatest difference is in June, 0.025 inch. The mean for the year at Tiberias was 0.08 inch, being four times greater than in England.

The numbers in the 7 th column show the mean monthly pressure of the atmosphere; the highest was 30.823 inches, in December, and the next in order 30.812 inches, in January; the lowest was 30.404 inches, in 


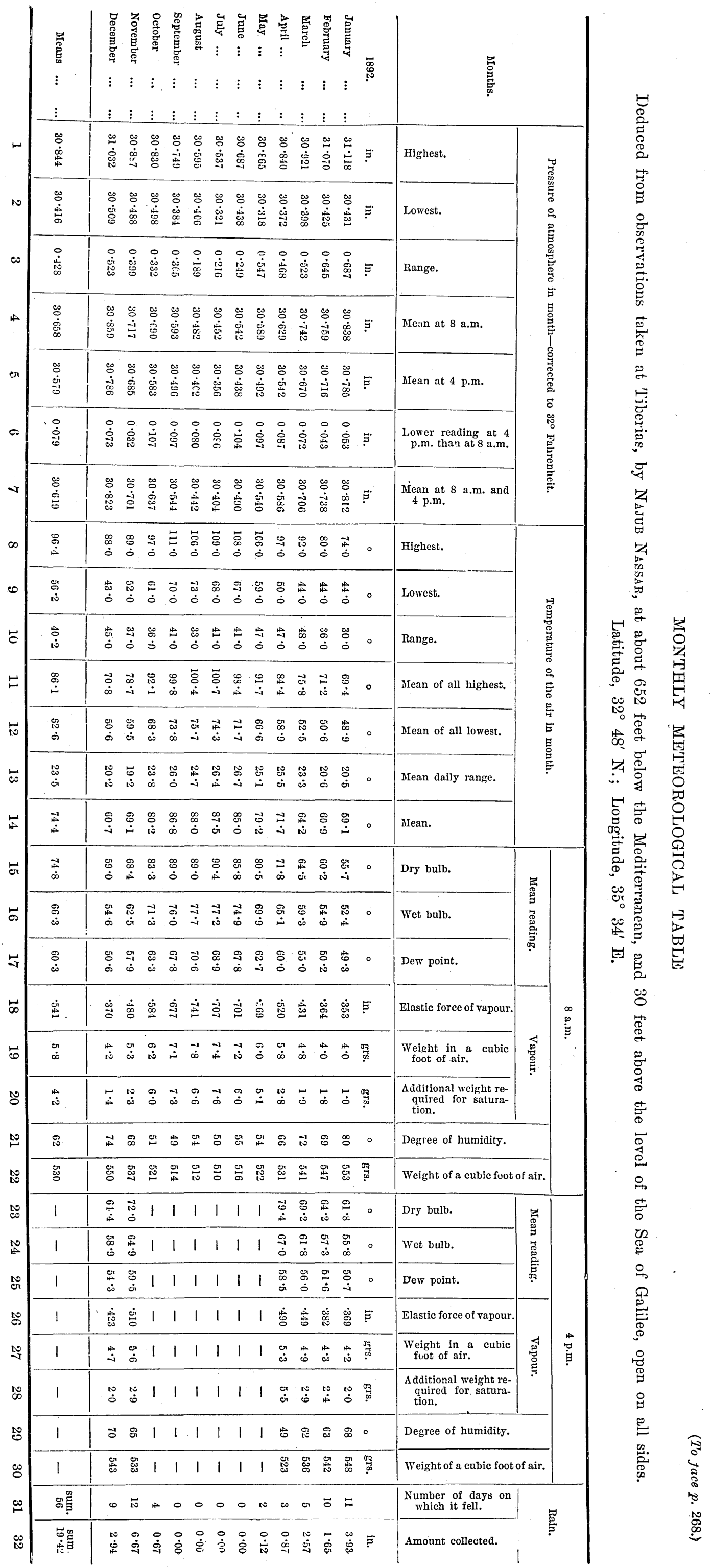


July, and the next in order 30.442 inches, in August. The mean for the year was $30^{\circ} 619$ inches.

The highest temperature of the air in each month is shown in column 8. The first day in the year the temperature reached $90^{\circ}$ was on March 9th ; in April the temperature reached or exceeded $90^{\circ}$ on 6 days; in May on 17 days ; in June, July, August, and September it reached or exceeded $90^{\circ}$ on every day; and in October on 28 days; thus the temperature reached or exceeded $90^{\circ}$ on 174 days during the year. At Jerusalem the temperature did not reach $90^{\circ}$ till May 14 th, and there were only 23 days in the year on which the temperature was as high as $90^{\circ}$. At Tiberias the temperature was as high as $101^{\circ}$ on May 6th, and reached or exceeded $100^{\circ}$ on 2 other days in this month; in June it reached or exceeded $100^{\circ}$ on 10 days; in July on 20 days; in August on 21 days ; and in September on 13 days; thus on 67 days in the year the temperature reached or exceeded $100^{\circ}$; at Jerusalem the temperature reached or exceeded $100^{\circ}$ on only one day. The highest temperature in the year at Tiberias was $111^{\circ}$, on September 15 th and $16 \mathrm{th}$; at Jerusalem the highest in the year was $101^{\circ}$, on September 17 th.

The lowest temperature of the air in each month is shown in column 9. The lowest in the year was $43^{\circ} 0$, on December 19th. The next lowest was $44^{\circ}$, on January 26th, February 29th, and March 1st, and there was no temperature so low as $44^{\circ}$ on any other night, the nearest approach was $45^{\circ}$ on January 24th. At Jerusalem the lowest in the year was $36^{\circ}$ on 3 nights, viz., January 26th, and December 19th and 20th ; and there were 19 nights in the year when the temperature was as low or lower than $40^{\circ}$.

The yearly range of temperature was $68^{\circ}$; at Jerusalem it was $65^{\circ}$.

The range of temperature in each month is shown in column 10 ; and these numbers vary from $30^{\circ}$ in January, to $48^{\circ}$ in March. At Jerusalem the range varied from $26^{\circ}$ in January to $43^{\circ}$ in April.

In column 11 the mean of all the high day temperatures in each month is shown. The lowest was $69^{\circ} .4$ in January, being $17^{\circ}$ higher than at Jerusalem; the next in order were $70^{\circ} .8$ in December, and $71^{\circ} \cdot 2$ in February ; the highest was $100^{\circ} .7$ in July, and the next in order were $100^{\circ} .4$ in August, and $99^{\circ} .8$ in September. At Jerusalem the lowest were $52^{\circ} \cdot 4$ in January, $56^{\circ} \cdot 0$ in December, and $56^{\circ} \cdot 7$ in February; the highest were $88^{\circ}$ in September, $87^{\circ} \cdot 1$ in August, and $85^{\circ} \cdot 6$ in July. The mean for the year at Tiberias was $86^{\circ} \cdot 1$; at Jerusalem it was $72^{\circ} \cdot 4$.

In column 12 the mean of all the low night temperatures in each month is shown; the lowest was $48^{\circ} .9$ in January, and the next in order $50^{\circ} 6$, in both February and December ; the highest was $75^{\circ} \cdot 7$ in August; the next in order were $74^{\circ} \cdot 3$ in July, and $73^{\circ} .8$ in September. At Jerusalem the lowest were $41^{\circ} \cdot 3$ in January, $43^{\circ} \cdot 2$ in February, and $44^{\circ} \cdot 3$ in December; the highest were $65^{\circ} \cdot 9$ in September, $64^{\circ} \cdot 6$ in August, and $63^{\circ} \cdot 7$ in July. At Tiberias the yearly value was $62^{\circ} \cdot 6$; at Jerusalem it was $54^{\circ} \cdot 5$.

In column 13 the mean daily range of temperature is shown in each 
month ; the smallest was $19^{\circ} \cdot 2$ in November, and the next in order were $20^{\circ} \cdot 2$ in December, and $20^{\circ} \cdot 5$ in January ; the greatest was $26^{\circ} .7$ in June, and the next in order $26^{\circ} .4$ in July, and $26^{\circ} .0$ in September. At Jerusalem the smallest were $11^{\circ} \cdot 1$ in January, $11^{\circ} .7$ in December, and $12^{\circ} .8$ in November; the greatest were $22^{\circ} .5$ in August; $22^{\circ} \cdot 1$ in September, and $22^{\circ} 0$ in June. The mean daily range for the year at Tiberias was $23^{\circ} \cdot 5$; at Jerusalem it was $17^{\circ} \cdot 9$.

The mean temperature of the air; as found from the maximum and minimum temperatures only, is shown in each month in column 14. The lowest was $59^{\circ} \cdot 1$ in January, and the next in order were $60^{\circ} \cdot 7$ in December, and $60^{\circ} .9$ in February ; the highest was $88^{\circ}$ in August, the next in order were $87^{\circ} .5$ in July, and $86^{\circ} .8$ in September. At Jerusalem the lowest were $46^{\circ} .8$ in January, $50^{\circ} .0$ in February, and $50^{\circ} .2$ in December ; the highest were $77^{\circ} 0$ in September, $75^{\circ} .8$ in August, and $74^{\circ} \cdot 7$ in July. At Tiberias the mean temperature increased month by month from the minimum in January to the maximum in August, then decreased month by month to the end of the year. At Tiberias the yeariy value was $74^{\circ} \cdot 4$; at Jerusalem it was $63^{\circ} \cdot 5$.

The numbers in the 15 th and 16 th columns are the mean readings of $a$ dry and wet-bulb thermometer, taken daily at 8 a.m. If those in column 15 be compared with those in column 14, it will be seen that thosè in column 15 were a little lower in January, February, November, and December, and a little higher in all other months. The mean for the year was $74^{\circ} \cdot 8$, differing by $0^{\circ} 4$ from the mean of the year as determined by the use of the maximum and minimum thermometers; should this be the case in future years, the mean temperature may be approximately determined by a single reading of the thermometers taken daily at $8 \mathrm{a} . \mathrm{m}$.

The numbers in column 17 are the temperature of the dew-point, or that temperature at which the air would be saturated by the quantity of vapour mixed with it; the smallest difference between these numbers and those in column 15 was $6^{\circ} \cdot 4$ in January; from April to November the smallest difference was $10^{\circ} .5$ in November, and the largest, $21^{\circ} .5$, in July.

The numbers in column 18 show the elastic force of vapour, or the length of a column of mercury in inches corresponding to the pressure of vapour; the smallest was 0.353 inch, in January, and the largest, 0.741 inch, in August.

In column 19 the weight in grains of the water in a cubic foot of air is shown ; it was as small as 4 grains in both January and February, and as large as $7 \frac{3}{4}$ grains in August.

In column 20 the additional quantity of water required to saturate a cubic foot of air is shown; it was as small as one grain in January, and as large as $7 \frac{1}{2}$ grains in July.

The numbers in column 21 show the degree of humidity of the air, satiration being represented by 100 ; the largest numbers appear from November to March, and the smallest from A pril to October, the smallest of all was 49 in September. 
The numbers in column 22 show the weight in grains of a cubic font of air, under the mean atmospheric pressure, temperature, and humidity of the air ; the largest number was in January, decreasing to the smallest in July, then increasing to December.

In column 31 are given the numbers of days of rain in each month ; the largest was 12 in November, and the next in order 11 in January. The total number in the year was 56. At Jerusalem rain fell on 63 days.

In column 32 the monthly fall of rain is given. The heaviest fall of rain on one day in the months from January to April was 1.45 inch, on January 1st ; the next in order were 0.90 inch and 0.72 inch on March 22nd and 23rd respectively. No rain fell from May 3rd till October 29th, making a period of 178 consecutive days without rain; the fall of rain on November 26th was 1.62 inch, and on November 30th and December 1st 1.30 inch and 1.42 inch fell respectively. The heaviest monthly fall in the year was 6.67 inches, in November, and the next in order 3.93 inches, in January. The total fall for the year was $19 \cdot 42$ inches. At Jerusalem the total fall for the year was $31 \cdot 23$ inches.

\title{
A NEW TREATISE ON THE GEOLOGY OF THE HOLY LAND AND THE DEAD SEA.1
}

\author{
By Edward HulL, LL.D., F.R.S., F.G.S.
}

WE welcome the treatise of Dr. Blanckenkorn on a subject which can never fail to interest those who make a study of the physical features .of the globe, especially when represented by a region confessedly unique in its geological structure, and one which must necessarily afford fresh objects of investigation, and new methods of treatment, from successive observers. The Palestine Exploration Society of this country has its counterpart in Germany; and with both societies the investigation of the geological structure of the Holy Land, and the mode of formation of the Dead Sea and of the Jordau-Arabah depression, has been undertaken as an essential part of the objects for which each society was founded.

The treatise of Dr. Blanckenkorn deals with those physical cnanges of which the Dead Sea depression, and the deeply furrowed ridge of Western Palestine, together with the tablelands of Edom and Moab are the outcome. Those who are familiar with the work of previous observers will not find in the essay of Dr. Blanckenkorn much that is new; but it is gratifying to know that there is very little in which he

1 "Entstehung und Geschichte des Todten Meeres," Von D. M. Blanckenkorn; "Zeit. d. Deutsch. Palæstina-Vereins," ed. by Professor D. Hermann Guthe (Leipsig, 1896). 